Article

\title{
Discovery and Characterization of Two Novel Salt-Tolerance Genes in Puccinellia tenuiflora
}

\section{Ying Li ${ }^{1}$, Tetsuo Takano ${ }^{2}$ and Shenkui Liu ${ }^{1, *}$}

1 Key Laboratory of Saline-alkali Vegetation Ecology Restoration in Oil Field (SAVER), Ministry of Education, Alkali Soil Natural Environmental Science Center (ASNESC), Northeast Forestry University, Harbin Hexing Road, Harbin 150040, China; E-Mail:1y7966@163.com

2 Asian Natural Environmental Science Center, University of Tokyo, Nishitokyo-shi, Tokyo 188-0002, Japan; E-Mail: takano@anesc.u-tokyo.ac.jp

* Author to whom correspondence should be addressed; E-Mail: shenkuiliu@nefu.edu.cn; Tel./Fax: +86-451-8219-1394.

Received: 22 July 2014; in revised form: 25 August 2014 / Accepted: 5 September 2014 / Published: 18 September 2014

\begin{abstract}
Puccinellia tenuiflora is a monocotyledonous halophyte that is able to survive in extreme saline soil environments at an alkaline $\mathrm{pH}$ range of 9-10. In this study, we transformed full-length cDNAs of $P$. tenuiflora into Saccharomyces cerevisiae by using the full-length cDNA over-expressing gene-hunting system to identify novel salt-tolerance genes. In all, 32 yeast clones overexpressing $P$. tenuiflor cDNA were obtained by screening under $\mathrm{NaCl}$ stress conditions; of these, 31 clones showed stronger tolerance to $\mathrm{NaCl}$ and were amplified using polymerase chain reaction (PCR) and sequenced. Four novel genes encoding proteins with unknown function were identified; these genes had no homology with genes from higher plants. Of the four isolated genes, two that encoded proteins with two transmembrane domains showed the strongest resistance to $1.3 \mathrm{M} \mathrm{NaCl}$. RT-PCR and northern blot analysis of $P$. tenuiflora cultured cells confirmed the endogenous $\mathrm{NaCl}$-induced expression of the two proteins. Both of the proteins conferred better tolerance in yeasts to high salt, alkaline and osmotic conditions, some heavy metals and $\mathrm{H}_{2} \mathrm{O}_{2}$ stress. Thus, we inferred that the two novel proteins might alleviate oxidative and other stresses in P. tenuiflora.
\end{abstract}

Keywords: salt stress; halophyte; Puccinellia tenuiflora; salt-tolerant FOX-yeast lines 


\section{Introduction}

In the natural environment, plants are often subjected to salinity, drought, low temperature and other external abiotic stresses. These adverse stresses affect normal physiological and biochemical activities, which seriously hinder the normal growth of plants. Salt stress is one of the major important abiotic stress factors in nature [1-3]. More than $6 \%$ of the land area (about 800 million hectares) worldwide is adversely affected by salt [4]. In northeast China, the area covered by saline-alkaline soil has reached 32 million ha, and the $\mathrm{pH}$ of such soils is more than 9.8 [5]. Saline-alkaline erosion might accelerate the loss of arable land in the medium term, with a projected loss of up to $50 \%$ by 2050 [6]. The effect of salt stress on plant growth is a result of the combined action of many factors. These factors affect photosynthesis and various physiological and biochemical pathways, thereby retarding the growth of plants and probably even leading to their death [7-11]. Therefore, understanding the mechanisms by which halophytes tolerate salt stress is critical. Indeed, the discovery of genes responsible for the core signaling pathways involved in the mitigation of salt stress might allow the generation of genetically engineered plants with more favorable agricultural properties.

Loss-of-function knockout mutants and activation-tagged gain-of-function mutants are widely used for the screening and analysis of gene functions in model plants, such as Arabidopsis thaliana and Oryza sativa [12-22]. On the basis of these approaches, researchers have developed an alternative approach, the full-length cDNA over-expressing gene (FOX)-hunting system, which is faster and more economical. This method does not require any prior knowledge regarding the genome of interest or genetic mapping. The FOX-hunting system was first proposed as a selective screening technique for plant functional genes in 2006. In A. thaliana, this technique has been used to produce numerous dominant mutants, which has facilitated the elucidation of gene functions through phenotypic analysis [23]. Nakamura et al. [24] generated 12,000 transgenic rice strains, named as FOX-rice lines, which ectopically expressed rice full-length cDNAs under the control of the maize ubiquitin promoter and revealed that $O s G L K 1$ regulated chloroplast development. Nonetheless, this technique is not limited to intraspecific strategies. Thellungiella salsuginea is a halophilic plant with a close phylogenetic relationship with A. thaliana. A method similar to FOX-hunting was applied to identify salt-tolerance genes in transgenic Arabidopsis that overexpressed cDNAs from an expression library derived from T. salsuginea [25]. In all, 130 Arabidopsis FOX-superroot lines have been generated in bird's-foot trefoil (Lotus corniculatus) for the systematic functional analysis of root genes and the selection of mutants with interesting root growth characteristics [26]. This technique is suggested to be extremely well-suited for the analysis of genes that control root length in L. corniculatus. Furthermore, this technique was successfully applied to identify genes that facilitated the survival of Eichhornia crassipes under low sulfur conditions [27]. Taken together, these data show that the FOX-hunting system is a very effective tool in plant functional gene research and that it facilitates the elucidation of the function of genes that control metabolic pathways and determine plant morphological characteristics.

Puccinellia tenuiflora (family, Gramineae) is a monocotyledonous halophyte distributed in the northeast region of China. Unlike other halophytes, $P$. tenuiflora can survive in extreme saline soil environments at an alkaline $\mathrm{pH}$ range of 9-10 [28,29]. Thus, this plant can be considered as an excellent model system for elucidating the genes involved in salt tolerance. Our previous cDNA microarray and expressed sequence tag analyses revealed many biotic and abiotic stress-induced genes 
that are abundantly expressed in P. tenuiflora [30,31]. These analyses allowed us to better understand the mechanisms of salt tolerance mechanisms in this plant. However, numerous other genes with unknown function have been reported to be differentially expressed in P. tenuiflora under salt stress, indicating that other genetic networks are involved in the response to stress conditions.

\section{Results and Discussion}

\subsection{Selection of Salt-Tolerant FOX (Full-Length cDNA Over-Expressing Gene)-Yeast Lines from Yeast} Full-Length P. tenuiflora cDNA Libraries

More than $1.6089 \times 10^{6}$ full-length cDNAs were obtained, of which 1000 colonies were randomly obtained for sequencing. This revealed that over $90 \%$ of the cDNAs were full length, and the length of most of these cDNAs was distributed between 0.2 and $4.0 \mathrm{~kb}$, confirming the quality of the cDNA libraries [32]. These cDNA libraries were used to transform S. cerevisiae strain InVscI and used to screen salt-tolerant FOX-yeast lines. During the first selection, 170 yeast colonies were obtained and named as $\mathrm{NaCl}-1^{\#}$ through $\mathrm{NaCl}-170^{\#}$. Monoclonal yeast colonies were used for secondary selection and polymerase chain reaction (PCR) identification; from these, 32 salt-tolerant FOX-yeast lines containing cDNA insertions were found.

\subsection{Multi-Resistance and Sequence Analyses of Salt-Resistant FOX-Yeast Lines}

Under normal growth conditions, the growth of the 32 salt-tolerant FOX-yeast lines was similar to that of the control yeast transformed with the empty pAUR101 vector (vector control, Figure 1a). When the medium was supplemented with $1 \mathrm{M} \mathrm{NaCl}$, the growth of most salt-tolerant FOX-yeast lines were slightly improved compared with that of the vector control. When the $\mathrm{NaCl}$ concentration was increased to $1.3 \mathrm{M}$, the growth of the vector control was essentially blocked, whereas 31 of the 32 FOX-yeast lines continued to grow. Clones NaCl-158 ${ }^{\#}$ and $\mathrm{NaCl}-167^{\#}$ were particularly salt-tolerant. Thus, most colonies of FOX-yeast lines showed significantly increased salt tolerance.

The relationship between the 32 FOX-yeast lines and other adverse stresses was explored by conducting multi-resistance analysis under alkaline, oxidative, osmotic and heavy metal stresses (Figure 1b). In the presence of $26 \mathrm{mM} \mathrm{Na}_{2} \mathrm{CO}_{3}, 12 \mathrm{mM} \mathrm{NaHCO}_{3}, 3 \mathrm{M} \mathrm{H}_{2} \mathrm{O}_{2}$ and $1.8 \mathrm{M}$ sorbitol, most salt-tolerant FOX-yeast lines grew better than the vector control. The resistance profile was altered between FOX-yeast lines and the vector control after treatment with $8 \mathrm{mM} \mathrm{Cu}^{2+}$, which induced heavy metal stress (Figure 1). These data indicated that most colonies of FOX-yeast lines showed improved resistance to alkaline, oxidative and osmotic stresses. However, the FOX-yeast lines showed different resistance responses to heavy metal stress; the reason for this phenomenon was not investigated in the present study.

After multi-resistance analysis, the salt-tolerant FOX-yeast lines were subjected to molecular analysis. The sequences of primers used are listed in Table 1. Sequences were compared and analyzed using the BLAST program of the National Centre of Biotechnology Information [33]. Open reading frame (ORF) searches were conducted using ORF Finder from NCBI [34]. Full-length cDNA sequences are listed in Table 2. Thirty-two sequences were full-length cDNAs, and they had complete coding sequences with fragment lengths between 650 and 4000 bp. Inserts from the 25 FOX-yeast 
lines had known functions and high homology with the genes found in higher plants (such as Arabidopsis, rice, barley and corn). The homology of one unknown gene was similar to that of Zea mays, and four unknown genes were slightly homologous with those in lower organisms.

Figure 1. The growth of 32 salt-tolerant Fox-yeast lines yeast cells in the presence of various abiotic stresses. (a) The salt-tolerant Fox-yeast lines improved salt tolerance ability of yeast; (b) the salt-tolerant Fox-yeast lines improved other abiotic stress tolerance abilities of yeast.
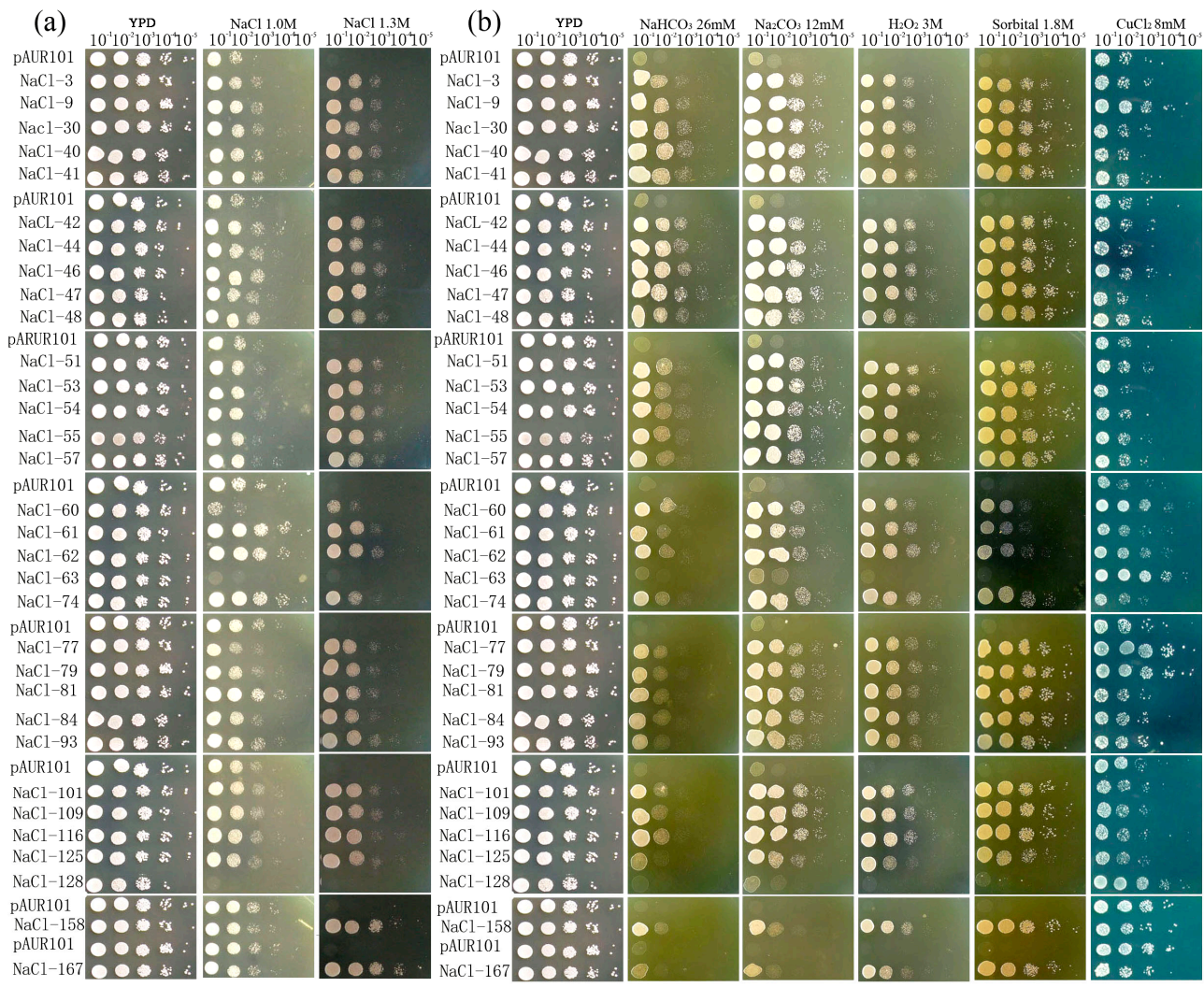

Table 1. Details of the primers used for polymerase chain reaction analysis.

\begin{tabular}{|c|c|}
\hline Primer Name & Sequences (from 5' to 3') \\
\hline pAUR101-FW & CCGGATCGGACTACTAGCAGCTG \\
\hline pAUR101-RV & TAGGGACCTAGACTTCAGGTTGTC \\
\hline $\mathrm{pYES}_{2}$-construct-F158 & $\underline{\text { GGATCCCCGGATCGGACTATAGCAGCTG }}$ \\
\hline pYES $_{2}$-construct-R158 & TCTGGATAGGGACCTAGACTTCAGGTTGTC \\
\hline $\mathrm{pYES}_{2}$-construct-F167 & GAATTCCCGGATCGGACTATAGCAGCTG \\
\hline pYES $_{2}$-construct-R167 & CTCGAGTAGGGACCTAGACTTCAGGTTGTC \\
\hline Put-tubulin-F & GTGTCAGCCATACTGTGCCAATC \\
\hline Put-tubulin-R & TTGCTCATGCGGTCAGCAATACC \\
\hline $\mathrm{NaCl}-158^{\#}-\mathrm{F}$ & GAGCAGAGGAGCAAGATG \\
\hline $\mathrm{NaCl}-158^{\#}-\mathrm{R}$ & TTACACGGAGGACAGACAC \\
\hline $\mathrm{NaCl}-167^{\#}-\mathrm{F}$ & ACAGTTGGGAGGAGCGTC \\
\hline $\mathrm{NaCl}-167^{\#}-\mathrm{R}$ & CCACTCGATCTGCATTTCT \\
\hline
\end{tabular}

Underlines were restriction sites. 
Table 2. Full-length cDNAs of $P$. tenuiflora isolated from the salt-tolerant transgenic yeast and their plant homologs.

\begin{tabular}{|c|c|c|c|c|}
\hline NO. & Superfamily & Description & $E$-Value & Species and Accession \\
\hline $\mathrm{NaCl}-3$ & RbcS superfamily & $\begin{array}{c}\text { ribulose-1,5-bisphosphate } \\
\text { carboxylase }\end{array}$ & $8 \times 10^{-117}$ & Triticum aestivum [P00871.2] \\
\hline $\mathrm{NaCl}-9$ & Metallothio 2 superfamily & $\begin{array}{c}\text { metallothionein-like } \\
\text { protein type } 2\end{array}$ & $2 \times 10^{-21}$ & Zea mays [ACF85243.1] \\
\hline $\mathrm{NaCl}-30$ & Chloroa b bind superfamily & $\begin{array}{l}\text { PSI type III chlorophyll } \\
\text { a/b-binding protein }\end{array}$ & $6 \times 10^{-92}$ & $\begin{array}{c}\text { Arabidopsis thaliana } \\
\text { [NP_001031217.1] }\end{array}$ \\
\hline $\mathrm{NaCl}-40$ & - & $\begin{array}{l}\text { glycine-rich cell wall } \\
\text { structural protein }\end{array}$ & $3 \times 10^{-5}$ & Oryza sativa [EAY86471.1] \\
\hline $\mathrm{NaCl}-41$ & NAD binding 8 superfamily & $\begin{array}{l}\text { thiamin biosynthetic } \\
\text { enzyme }\end{array}$ & 0.0 & Triticum urartu [EMS66450.1] \\
\hline $\mathrm{NaCl}-42$ & - & $\begin{array}{l}\text { hypothetical protein } \\
\text { ZEAMMB73879106 }\end{array}$ & - & Zea mays [AFW58868.1] \\
\hline $\mathrm{NaCl}-44$ & AAI LTSS superfamily & lipid transfer protein & $8 \times 10^{-44}$ & $\begin{array}{c}\text { Triticum aestivum } \\
\text { [ABB90546.1] }\end{array}$ \\
\hline $\mathrm{NaCl}-46$ & PP-binding superfamily & acyl carrier protein 3 & $9 \times 10^{-63}$ & Zea mays [ACG24988.1] \\
\hline $\mathrm{NaCl}-47$ & $\begin{array}{c}\text { Plant peroxidase like } \\
\text { superfamily }\end{array}$ & Peroxidase & $1 \times 10^{-165}$ & $\begin{array}{c}\text { Glycine max } \\
{[\mathrm{XP} \text { 003517206.1] }}\end{array}$ \\
\hline $\mathrm{NaCl}-48$ & - & Dehydrin & $3 \times 10^{-58}$ & $\begin{array}{c}\text { Hordeum vulgare } \\
\text { [CAA50499.1] }\end{array}$ \\
\hline $\mathrm{NaCl}-51$ & $\begin{array}{c}\text { DIOX-N superfamily ACC } \\
\text { oxidase }\end{array}$ & ACC oxidase & $5 \times 10^{-140}$ & $\begin{array}{c}\text { Glycine } \max \\
{[\mathrm{NP} \text { 001276303.1] }}\end{array}$ \\
\hline $\mathrm{NaCl}-53$ & - & $\begin{array}{l}\text { nucleic acid binding/ } \\
\text { zinc ion binding }\end{array}$ & $2 \times 10^{-31}$ & $\begin{array}{c}\text { Arabidopsis thaliana } \\
\text { [NP_001154741.1] }\end{array}$ \\
\hline $\mathrm{NaCl}-54$ & - & unknown & 0.35 & - \\
\hline $\mathrm{NaCl}-55$ & UBQ superfamily & Polyubiquitin3 & $2 \times 10^{-167}$ & $\begin{array}{c}\text { Arabidopsis thaliana } \\
\text { [NP_851029.1] }\end{array}$ \\
\hline $\mathrm{NaCl}-57$ & Ribosomal-S7e superfamily & 40S ribosomal protein $\mathrm{S} 7$ & $2 \times 10^{-5}$ & $\begin{array}{c}\text { Cucumis sativus } \\
{[\mathrm{XP} \text { 004137317.1] }}\end{array}$ \\
\hline $\mathrm{NaCl}-60$ & - & $\begin{array}{l}\text { neurogenic locus notch } \\
\text { protein precursor-like }\end{array}$ & $5 \times 10^{-89}$ & Zea mays [NP_001158958.1] \\
\hline $\mathrm{NaCl}-61$ & $\begin{array}{l}\text { Ribokinase-pfkB-like } \\
\text { superfamily }\end{array}$ & fructokinase-2 & $5 \times 10^{-154}$ & $\begin{array}{c}\text { Arabidopsis thaliana } \\
\text { [NP 191507.1] }\end{array}$ \\
\hline $\mathrm{NaCl}-62$ & Cupin-2 superfamily & germin-like protein & $2 \times 10^{-92}$ & $\begin{array}{c}\text { Arabidopsis thaliana } \\
\text { [AAB51752.1] }\end{array}$ \\
\hline $\mathrm{NaCl}-63$ & - & Unknown & - & - \\
\hline $\mathrm{NaCl}-74$ & $\begin{array}{l}\text { TIM-phosphate binding } \\
\text { superfamily }\end{array}$ & glycolate oxidase & $6 \times 10^{-72}$ & $\begin{array}{c}\text { Arabidopsis thaliana } \\
\text { [AAB80700.1] }\end{array}$ \\
\hline $\mathrm{NaCl}-77$ & Duf1313 superfamily & $\begin{array}{l}\text { EARLY flowering } \\
\text { protein }\end{array}$ & $5 \times 10^{-33}$ & Zea mays [ACG45265.1] \\
\hline $\mathrm{NaCl}-79$ & DOMON superfamily & auxin-responsive protein & $3 \times 10^{-116}$ & $\begin{array}{c}\text { Arabidopsis thaliana } \\
\text { [NP_199564.1] }\end{array}$ \\
\hline
\end{tabular}


Table 2. Cont.

\begin{tabular}{|c|c|c|c|c|}
\hline NO. & Superfamily & Description & $E$-Value & Species and Accession \\
\hline $\mathrm{NaCl}-81$ & $\begin{array}{l}\text { Glycosyltransferase-GTB-type } \\
\text { superfamily }\end{array}$ & $\begin{array}{l}\text { trehalose-6-phosphate } \\
\text { synthase }\end{array}$ & 0.0 & $\begin{array}{c}\text { Oryza sativa } \\
{[\mathrm{NP} \text { 001063104.1] }}\end{array}$ \\
\hline $\mathrm{NaCl}-84$ & PSI-psaK superfamily & $\begin{array}{l}\text { photosystem I reaction } \\
\text { center subunit psaK }\end{array}$ & $4 \times 10^{-52}$ & $\begin{array}{c}\text { Arabidopsis thaliana } \\
\text { [CAB53033.1] }\end{array}$ \\
\hline $\mathrm{NaCl}-93$ & Rubredoxin-like superfamily & rubredoxin family protein & $7 \times 10^{-62}$ & $\begin{array}{l}\text { Arabidopsis thaliana } \\
\text { [NP_001078598.1] }\end{array}$ \\
\hline $\mathrm{NaCl}-101$ & - & Unknown & $6 \times 10^{-11}$ & Zea mays [DAA58889.1] \\
\hline $\mathrm{NaCl}-109$ & PsbR superfamily & $\begin{array}{l}\text { PSBR (photosystem II } \\
\text { subunit R) }\end{array}$ & $7 \times 10^{-63}$ & $\begin{array}{c}\text { Oryza sativa Japonica Group } \\
\text { [BAC83336.1] }\end{array}$ \\
\hline $\mathrm{NaCl}-116$ & Ntn-hydrolase superfamily & $\begin{array}{l}\text { proteasome subunit beta } \\
\text { type } 4 \text { precursor }\end{array}$ & $3 \times 10^{-156}$ & Zea mays [ACG33740.1] \\
\hline $\mathrm{NaCl}-125$ & - & $\begin{array}{l}\text { homeodomain leucine } \\
\text { zipper protein }\end{array}$ & $2 \times 10^{-106}$ & Zea mays [AFW63782.1] \\
\hline $\mathrm{NaCl}-128$ & Ribosomal-L21e superfamily & 60 S ribosomal protein $\mathrm{L} 21$ & $3 \times 10^{-38}$ & Zea mays [DAA49694.1] \\
\hline $\mathrm{NaCl}-158$ & - & Unknown & - & - \\
\hline $\mathrm{NaCl}-167$ & - & Unknown & - & - \\
\hline
\end{tabular}

\subsection{Discovery of Two Novel Endogenous Genes of P. tenuiflora}

Two of the isolated genes $\left(\mathrm{NaCl}-158^{\#}\right.$ and $\left.\mathrm{NaCl}-167^{\#}\right)$ that conferred strong salt resistance had only low homology with some genes found in lower organisms, and their functions are not yet known. RT-PCR was used to amplify RNA from cultured cells of $P$. tenuiflora that were treated with $200 \mathrm{mM}$ $\mathrm{NaCl}$ for $12 \mathrm{~h}$ or that were left untreated. These two genes were highly expressed in P. tenuiflora after treatment with $200 \mathrm{mM} \mathrm{NaCl}$. This revealed that the two genes were strongly induced after salt stress (Figure 2). As we knew that culture cells were grown under strict sterile conditions, these exclude the possibility that we had inadvertently selected for growth of other microorganisms. These results further confirmed that the genes encoded by the cDNA inserts of $\mathrm{NaCl}-158^{\#}$ and $\mathrm{NaCl}-167^{\#}$ were expressed endogenously in P. tenuiflora and that these genes were salt inducible. Thus, we then investigated the expression patterns of the isolated genes under $\mathrm{NaCl}$ stress.

Figure 2. Expression of $\mathrm{NaCl}-158^{\#}$ and $\mathrm{NaCl}-167^{\#}$ in $P$. tenuiflora culture cells untreated and treated with $200 \mathrm{mM} \mathrm{NaCl}$ for $12 \mathrm{~h}$ by RT-PCR analysis.

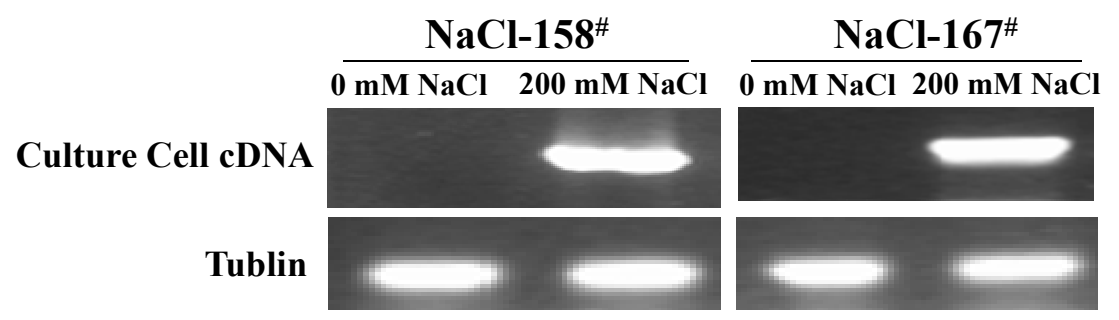

The primers shown in Table 1 were used to clone the full-length sequence of NaCl-158 ${ }^{\#}$ and NaCl-167" The cDNA of NaCl-158* was 1036 bp in length and encoded a protein of 84 amino acids (Figure 3a). The protein had two transmembrane structural domains, as predicted by an online software 
TMHMM-2.0 [35] (Figure 3a). Homologous nucleotide sequences were not detected in the NCBI database by BLASTN analysis. At the amino acid level, NaCl-158 ${ }^{\#}$ showed a low level of homology with the suppressor for copper sensitivity $(\mathrm{ScsB})$, a transmembrane protein isolated from Morganella morganii (ref|WP_004240832.1|). The cDNA of NaCl-167 ${ }^{\#}$ was $867 \mathrm{bp}$ and encoded a protein of 174 amino acids (Figure 3b). The protein encoded by this gene also had two transmembrane domains (Figure 3b). Homologous nucleotide sequences were not detected in the NCBI database by BLASTN analysis. At the amino acid level, $\mathrm{NaCl}-167^{\#}$ had low homology with a protein of unknown function, Azospirillum brasilense Sp245 (ref|YP_005030162.1|).

Figure 3. Sequence analysis of $\mathrm{NaCl}-158^{\#}$ and $\mathrm{NaCl}-167^{\#}$. (a) Open reading frame and transmembrane helix analysis of $\mathrm{NaCl}-158^{\#}$; (b) open reading frame and transmembrane helix analysis of $\mathrm{NaCl}-167^{\#}$.

\section{The Sequence and transmembrane helix of NaCl-158}

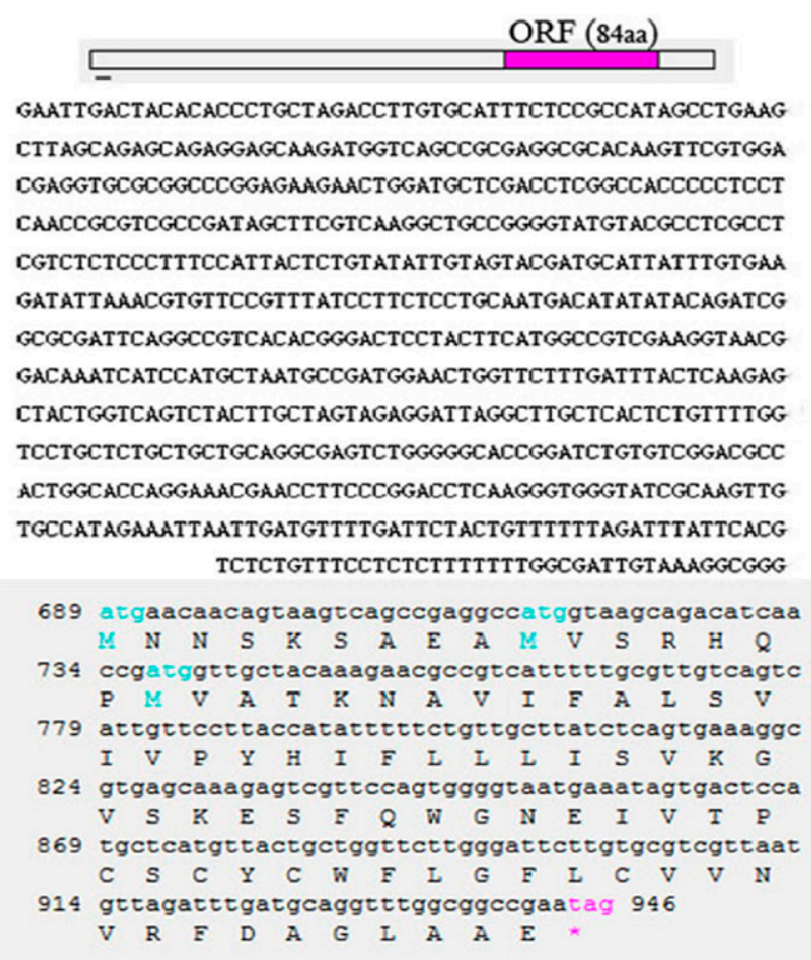

TGTATGTATATGTGTCTGTCCTCCGTGTAATAAATCTATTCGTTTTGTTAAAAA

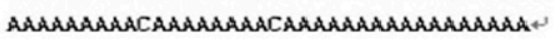

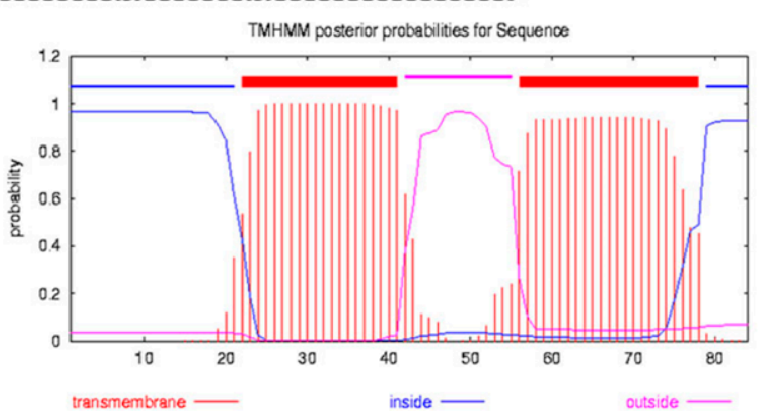

(a)

\section{The Sequence and transmembrane helix of $\mathrm{NaCl}-167^{\#}$

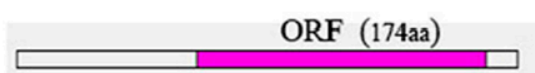

GAATTGGTCCTTATCTTTATCCACTGCTACAGTTGGGAGGAGCGTCGGGAGTCG CTTCCGACCCCGCCGGTGGAGCTGACCGTCTCCCTCGCCTACGATGACCTTTGGG GCGTCGTGAGGTGGGGGAGGCCGTCTGGCTGGTGGCTTAGGTCCTAGTTTTTATA GGCTTAGTATTCCGGCGAAGGCGTCGAGGCGAAGGCACGGCGACGCCATGGAMT AAGGTCCTCCCTAGCTCTTCCTCGCCTCGTTGGTGCGTCACTCCGGCGCCGGCGA CGAGCTTGTGGAGGTGGGTTCTGTCTACGAACTCC

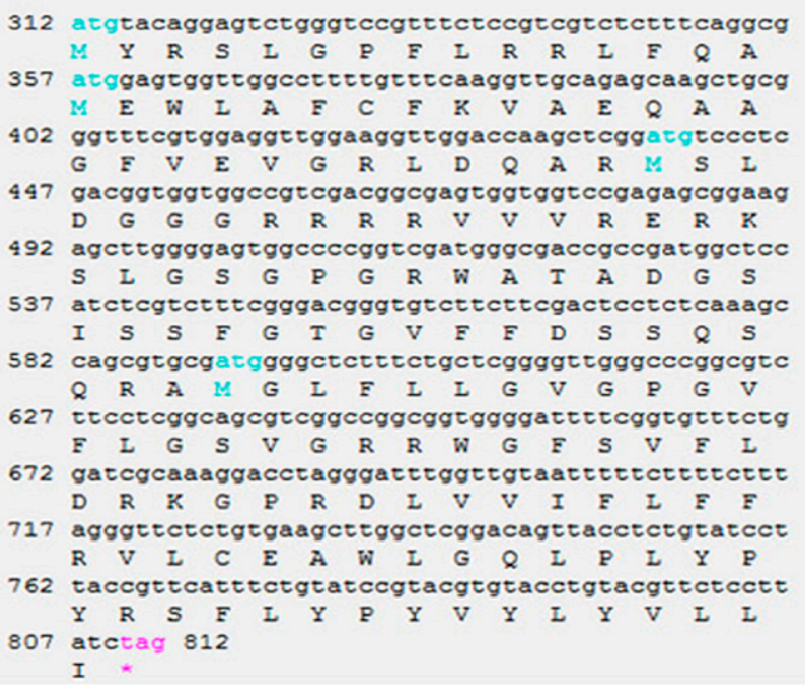

ALATGCAGATCGAGTGGTCACCGACGAACCCAAACARAdAdAdAdAdAdAdAAAA

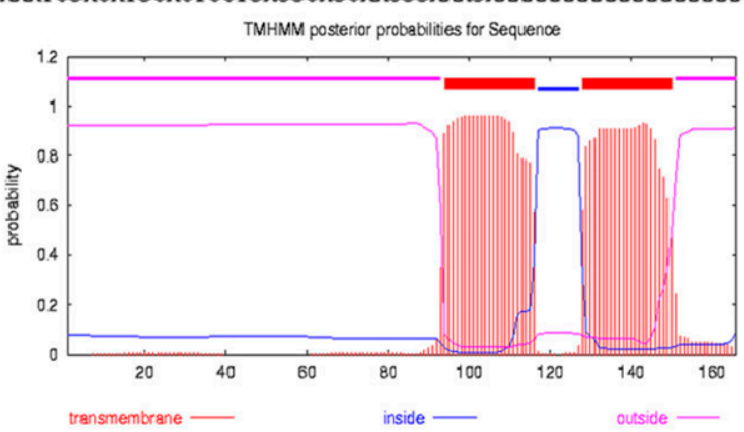

(b) 


\subsection{Expression Patterns of $\mathrm{NaCl}-158^{\#}$ and $\mathrm{NaCl}-167^{\#}$}

The expression patterns of $\mathrm{NaCl}-158^{\#}$ and $\mathrm{NaCl}-167^{\#}$ were analyzed using northern blot analysis. $\mathrm{NaCl}-158^{\#}$ and $\mathrm{NaCl}-167^{\#}$ were found to be constitutively expressed in P. tenuiflora. NaCl-158 ${ }^{\#}$ was expressed in stems and flowers, as well as in leaves and roots at high levels, but not in seeds (Figure 4a). NaCl-167" was expressed in roots, stems, leaves and seeds; it was highly expressed in roots, in low levels in leaves, but not in flowers (Figure 4b).

Figure 4. Expression analysis of $\mathrm{NaCl}-158^{\#}$ and $\mathrm{NaCl}-167^{\#}$ by northern blot analysis. (a) Analysis of the expression pattern of $\mathrm{NaCl}-158^{\#}$ by northern blot. RNA was isolated from roots (R), stems (St), leaves (L), flowers $(\mathrm{F})$ and seeds $(\mathrm{S})$. The response of NaCl-158 to salt stress of $P$. tenuiflora culture cells treated with $200 \mathrm{mM} \mathrm{NaCl}$ solution for the indicated times before the RNA was isolated; (b) Analysis of the expression pattern of $\mathrm{NaCl}-167^{\#}$ by northern blot. RNA was isolated from roots (R), stems (St), leaves (L), flowers (F) and seeds (S). The response of $\mathrm{NaCl}-167^{\#}$ to salt stress of P. tenuiflora culture cells treated with $200 \mathrm{mM} \mathrm{NaCl}$ solution for the indicated times before the RNA was isolated.

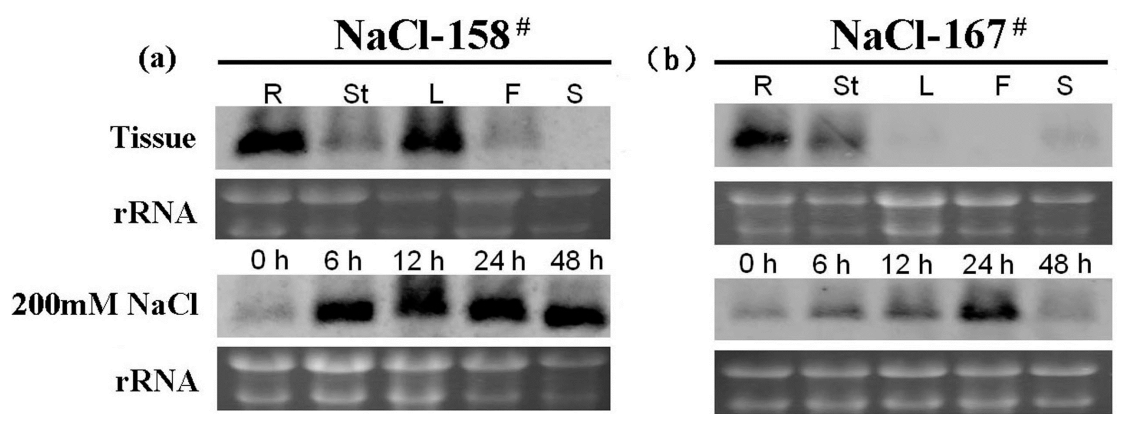

Subsequently, the expression of $\mathrm{NaCl}-158^{\#}$ and $\mathrm{NaCl}-167^{\#}$ was monitored over a time course after cultured $P$. tenuiflora was treated with $200 \mathrm{mM} \mathrm{NaCl}$. The NaCl-158 $8^{\#}$ transcript levels in the cultured cells increased remarkably after $\mathrm{NaCl}$ treatment, peaked at $6 \mathrm{~h}$ and remained high until $48 \mathrm{~h}$ (Figure 4a). On the other hand, the $\mathrm{NaCl}-167^{\#}$ transcript levels in the cultured cells increased remarkably after $\mathrm{NaCl}$ treatment, peaked at $24 \mathrm{~h}$ and then decreased (Figure $4 \mathrm{~b}$ ). These results showed that $\mathrm{NaCl}-158^{\#}$ and $\mathrm{NaCl}-167^{\#}$ are constitutively expressed in P. tenuiflora and can be induced by $\mathrm{NaCl}$ stress.

\subsection{Overexpression of $\mathrm{NaCl}-158^{\#}$ and $\mathrm{NaCl}-167^{\#}$ in Yeast under Various Stress Conditions}

$\mathrm{NaCl}-158^{\#}$ and $\mathrm{NaCl}-167^{\#}$ are genes encoding proteins with unknown function; both proteins have two predicted transmembrane helices (Figure 3). Therefore, we speculated that these proteins might be involved in ion transport and, thus, performed metal cation-resistance analysis experiments. The two cDNAs (NaCl-158 $8^{\#}$ and $\mathrm{NaCl}-167^{\#}$ ) were cloned into the expression vector, $\mathrm{pYES}_{2}$, to generate transgenic yeast. The strains were used to determine whether $\mathrm{NaCl}-158^{\#}$ and $\mathrm{NaCl}-167^{\#}$ could confer resistance to various metal cations. Each gene showed slightly different growth profiles in their hosts in response to different cations (Figure 5). 
Figure 5. The growth of overexpressing yeast cells in the presence of various metal ions.

(a) The growth of $p Y E S_{2}-\mathrm{NaCl}-158^{\#}$ yeast cells in the presence of various metal ions;

(b) the growth of $p Y E S_{2}-\mathrm{NaCl}-167^{\#}$ yeast cells in the presence of various metal ions.
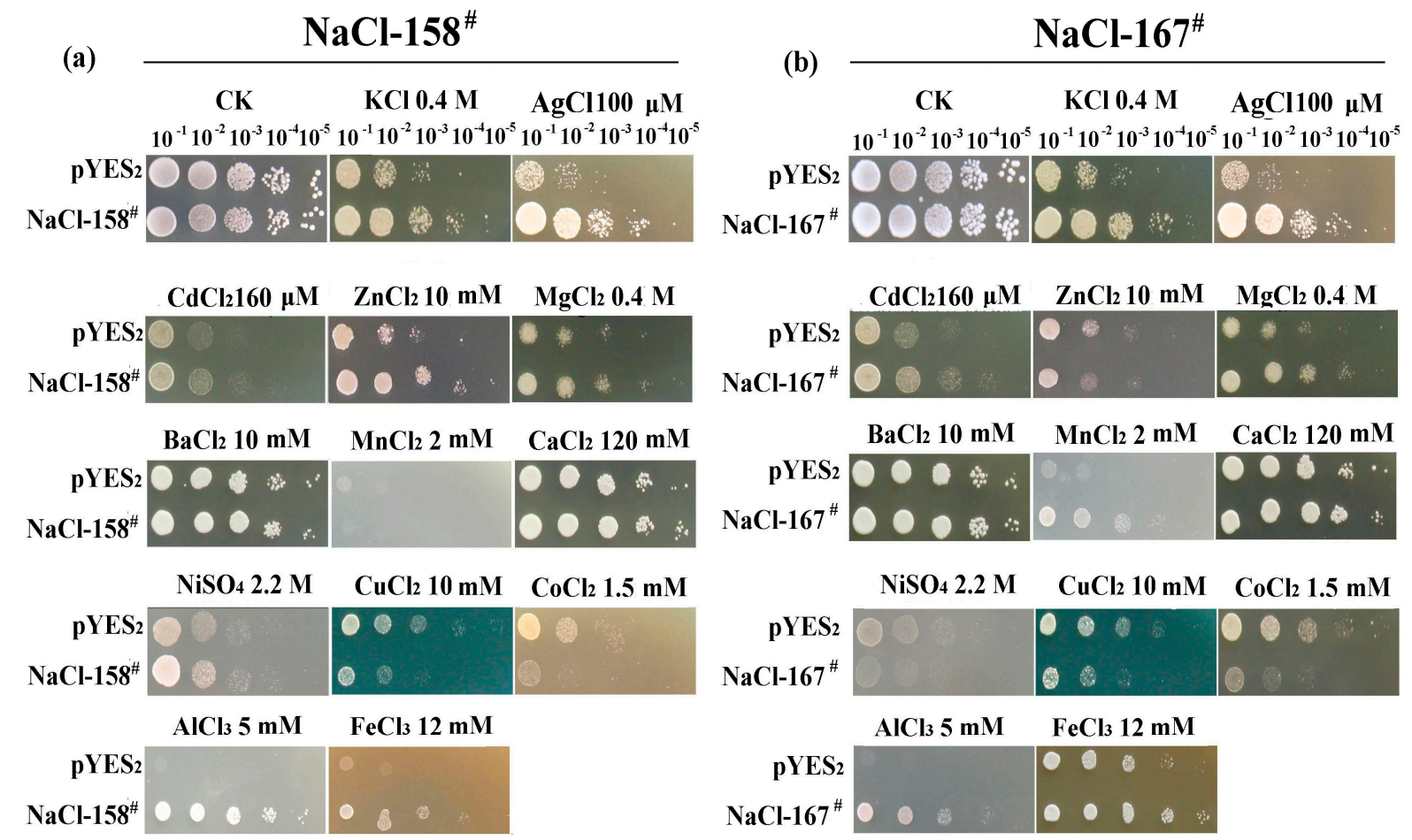

The growth of $\mathrm{NaCl}-158^{\#}$ transformants was similar to that of the vector control $(\mathrm{pYES} 2)$ on contrast check (CK) media, but was considerably better than that of the vector control on media containing $\mathrm{Ag}^{+}, \mathrm{Al}^{3+}$ and $\mathrm{Fe}^{3+}$; growth was slightly improved in the presence of $\mathrm{K}^{+}, \mathrm{Zn}^{2+}, \mathrm{Ni}^{2+}$ and $\mathrm{Cd}^{2+}$ and was almost the same as that of the control in the presence of $\mathrm{Mg}^{2+}, \mathrm{Ba}^{2+}, \mathrm{Mn}^{2+}$ and $\mathrm{Ca}^{2+}$. In contrast, the cells were hyper-sensitive to $\mathrm{Cu}^{2+}$ and $\mathrm{Co}^{2+}$.

The growth of NaCl-167 ${ }^{\#}$ transformants was similar to that of the vector control (pYES 2 ) on CK media, but was considerably better than that of the vector control on media containing $\mathrm{K}^{+}, \mathrm{Ag}^{+}, \mathrm{Mn}^{2+}$, $\mathrm{Al}^{3+}$ and $\mathrm{Fe}^{3+}$; growth was slightly improved in the presence of $\mathrm{Cd}^{2+}$ and $\mathrm{Mg}^{2+}$ and was almost the same as that of control in the presence of $\mathrm{Ba}^{2+}, \mathrm{Ca}^{2+}$ and $\mathrm{Zn}^{2+}$. In contrast, the cells were slightly sensitive to $\mathrm{Ni}^{2+}$ and hyper-sensitive to $\mathrm{Cu}^{2+}$ and $\mathrm{Co}^{2+}$. Because of this heterogeneous response, the two transmembrane proteins could not be categorized as specific mediators of cation resistance.

The two yeast transformants of $\mathrm{NaCl}-158^{\#}$ and $\mathrm{NaCl}-167^{\#}$ were also used to confirm salt tolerance (Figure 6). Under normal conditions, the growth of $\mathrm{NaCl}-158^{\#}$ and $\mathrm{NaCl}-167^{\#}$ transformants was similar to that of the vector control $\left(\mathrm{pYES}_{2}\right)$ on $\mathrm{CK}$ media. The growth of the vector control was blocked when the $\mathrm{NaCl}$ concentration reached $1.3 \mathrm{M}$, whereas the two yeast transformants continued to grow (Figure 1a). The protective effects of $\mathrm{NaCl}-158^{\#}$ and $\mathrm{NaCl}-167^{\#}$ in response to stress were generalized by challenging the yeast transformants to other abiotic stresses, including $\mathrm{NaHCO}_{3}$, $\mathrm{Na}_{2} \mathrm{CO}_{3}$, sorbitol and heavy metal $\left(\mathrm{CdCl}_{2}\right)$. Both $\mathrm{NaCl}-158^{\#}$ and $\mathrm{NaCl}-167^{\#}$ showed enhanced growth compared to that of the vector control on all of the media. A common adverse effect of all of these treatments was the generation of oxidative stress [36-39]. The growth of the two yeast transformants was considerably better than that of the vector control on media containing $\mathrm{H}_{2} \mathrm{O}_{2}$. Thus, we inferred 
that the two genes could confer resistance to oxidative stress. This might partially explain the resistance to metal cations, since they cause oxidative stress. However, two notable exceptions were $\mathrm{Cu}^{2+}$ and $\mathrm{Co}^{2+}$, since yeast cells overexpressing $\mathrm{NaCl}-158^{\#}$ and $\mathrm{NaCl}-167^{\#}$ were sensitive to these ions. This might be due to the specific aspects of $\mathrm{Cu}^{2+} / \mathrm{Co}^{2+}$ metabolism in yeast. Yeasts are eukaryotes; their metabolic pathways are similar to those of plants. Our experimental results in yeasts provided the primary basis for performing further studies. Investigating the function of these two genes in plants is necessary to determine the mechanism of how these two genes confer stress tolerance.

Figure 6. The growth of overexpressing yeast cells in the presence of various abiotic stresses. (a) The growth of $p Y E S_{2}-\mathrm{NaCl}-158^{\#}$ yeast cells in the presence of various abiotic stresses; (b) the growth of $p Y E S_{2}-\mathrm{NaCl}-167^{\#}$ yeast cells in the presence of various abiotic stresses. The pictures show the growth of $p Y E S_{2}-\mathrm{NaCl}-158^{\#}$ and pYES $2-\mathrm{NaCl}-167^{\#}$ yeast cells in the presence of $\mathrm{CdCl}_{2}$ and are the same as the pictures from Figure 5.
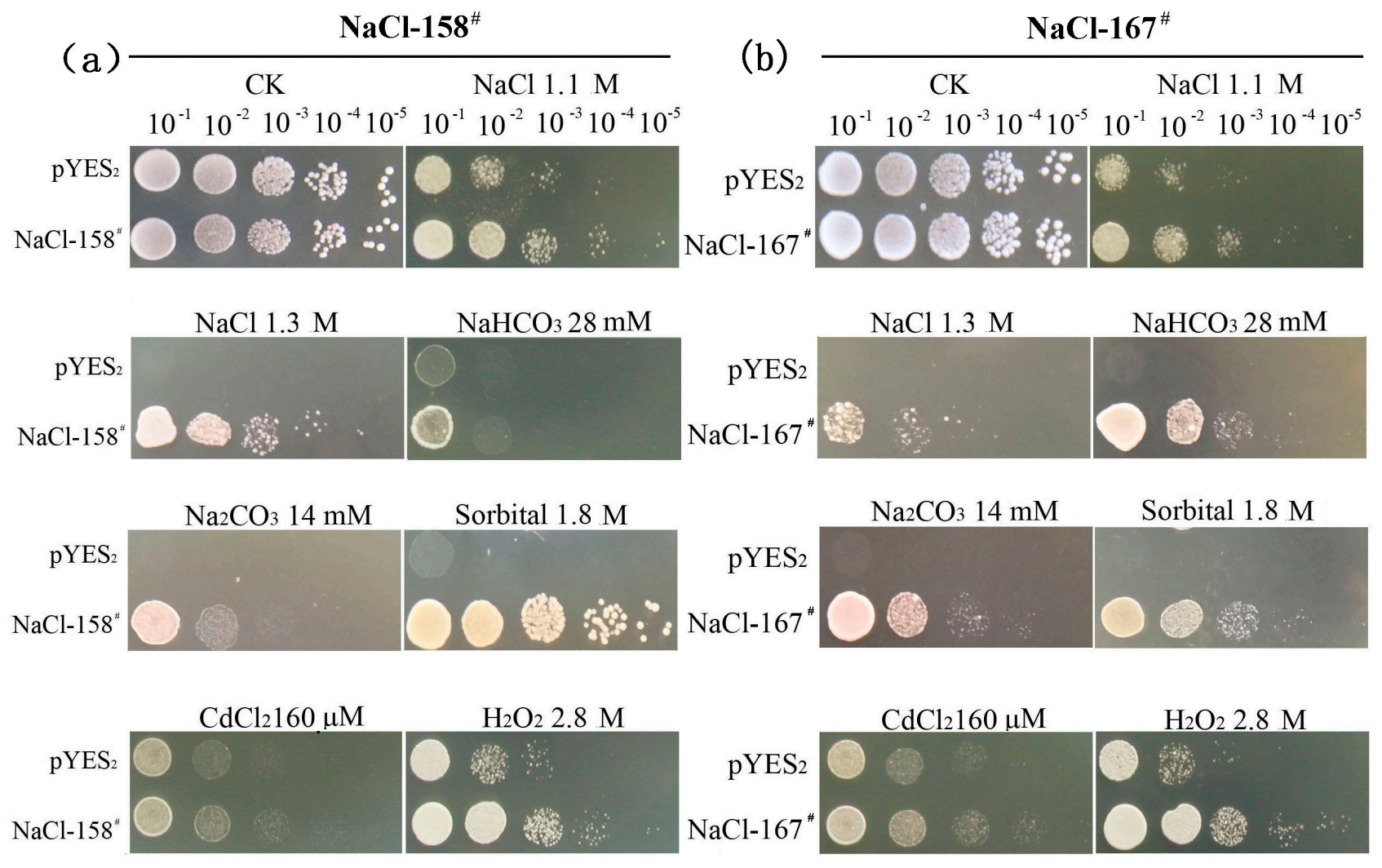

\section{Experimental Section}

\subsection{Materials}

Wild-type P. tenuiflora plants, tissues and organs (roots, stems, leaves, flowers and seeds) were collected from the Experimental Base Alkali Soil Natural Environmental Science Center (ASNESC), Northeast Forestry University (Harbin, China). These materials were used for RNA extraction and northern blot analysis. Cultured P. tenuiflora cells were treated with $200 \mathrm{mM} \mathrm{NaCl}$ for 0, 6, 12, 24 and 
$48 \mathrm{~h}$. RNA from these samples was used for RT-PCR and northern blot analyses. S. cerevisiae strain InVscI was used in the yeast transformation experiments.

\subsection{Constructs}

Construction of yeast expressing full-length cDNA libraries derived from $P$. tenuiflora: RNA samples extracted from seedlings ( $P$. tenuiflora) treated with $200 \mathrm{mM} \mathrm{NaCl}$ were used. Full-length cDNA libraries of $P$. tenuiflora were constructed using the pGCAP10 vector in 2008. SwaI and Not I restriction enzyme sites were introduced at the $5^{\prime}$ and $3^{\prime}$ ends of each cDNA. Libraries of yeast expressing full-length cDNAs were constructed by ligating the cDNAs to the pAUR101 vector (TaKaRa, Dalian, China) after digestion with SwaI and NotI; the vectors were then transformed into S. cerevisiae strain InVscI by Yeast Extract Peptone Dextrose Medium (YPD) using the LiAc/PEG yeast transformation method [40]. The transformed yeasts were cultivated on medium containing $50 \mathrm{mg} / \mathrm{L}$ abscisic acid (aba), with 3000-4000 clones on every plate. All yeast colonies were washed off the agar plates and completely resuspended. Suspensions were mixed with an equal volume of $80 \%$ glycerol, frozen in liquid nitrogen and stored at $-80^{\circ} \mathrm{C}$.

Plasmid constructs: Full-length sequences of $\mathrm{NaCl}-158^{\#}$ and $\mathrm{NaCl}-167^{\#}$ clones were amplified from yeast DNA by using the primers, YYES$_{2}$-construct-F158/pYES 2 -construct-R158 and $\mathrm{pYES}_{2}$-construct-F167/pYES 2 -construct-R167, respectively (Table 1). The amplified product was digested with restriction endonuclease and cloned into the yeast expression vector, pYES 2 (TaKaRa), to form $p Y E S_{2}-\mathrm{NaCl}-158^{\#}$ and $p Y E S_{2}-\mathrm{NaCl}-167^{\#}$ plasmids. All products were confirmed by sequencing before use in yeast resistance tests.

\subsection{Multiple Screening for Salt-Tolerant Transgenic Yeast Lines}

Salt-tolerant yeast lines were isolated from the full-length cDNA libraries by using multiple screening and high $\mathrm{NaCl}$ concentration $(1.3 \mathrm{M})$. Yeast library suspensions were activated, washed with sterile water 2-3 times, diluted with sterile water and coated with the solid medium, Yeast Extract Peptone Galactose Medium (YP-U), which contains $1.3 \mathrm{M} \mathrm{NaCl}$ and $2 \%$ galactose. Fifty replicates of plates containing 3000-4000 colonies/plate were interrogated to ensure full coverage of the cDNA libraries. Plates were incubated at $30{ }^{\circ} \mathrm{C}$ for 3-6 days; monoclonal FOX-yeast lines were selected and then cultured overnight in YPD liquid containing $50 \mathrm{mg} / \mathrm{L}$ aba. Cell density was adjusted on the basis of an $\mathrm{OD}_{600}$ of 0.5 , and cells were washed twice with sterile water; $5 \mu \mathrm{L}$ of diluted cells were spotted on $1.3 \mathrm{M}$ solid $\mathrm{NaCl}$ YP-U medium containing $2 \%$ galactose for secondary screening. The following day, FOX-yeast lines that grew normally in $1.3 \mathrm{M} \mathrm{NaCl} \mathrm{YP-U} \mathrm{medium} \mathrm{were} \mathrm{selected.} \mathrm{Concomitantly,}$ universal primers (pAUR101-FW and pAUR101-RV) were used to amplify DNA from the FOX-yeast lines identified in secondary screens. FOX-yeast lines that did not contain insertions were excluded from further analysis (the primers are shown in Table 1).

\subsection{Yeast Resistance Analysis Media and Growth Conditions}

All FOX-yeast lines and control strains cultured overnight were adjusted to an OD600 of 0.5. Ten-fold serial dilutions of all yeast were prepared (diluted over a five-log range of $10^{-1}, 10^{-2}, 10^{-3}$, 
$10^{-4}$ and $10^{-5}$ ). Five microliters of each dilution were spotted on solid YP-U medium containinga range of stress-inducing agents, including $1.0 \mathrm{M}$ and $1.3 \mathrm{M} \mathrm{NaCl}, 26 \mathrm{mM} \mathrm{NaHCO}, 12 \mathrm{mM} \mathrm{Na}_{2} \mathrm{CO}_{3}$, $3 \mathrm{M} \mathrm{H}_{2} \mathrm{O}_{2}, 1.8 \mathrm{M}$ sorbitol and $8 \mathrm{mM} \mathrm{CuCl}_{2}$ (containing $2 \%$ galactose), and YPD medium was used as the control. All plates were incubated at $30{ }^{\circ} \mathrm{C}$ for 3-6 days before growth was scored.

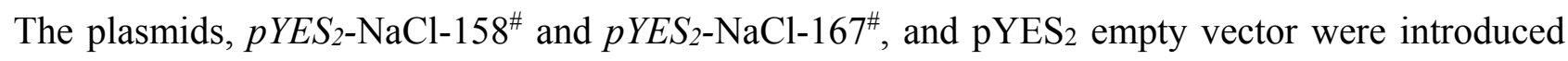
into yeast strain INVSCI. Ten-fold serial dilutions of yeast were prepared, and $5 \mu \mathrm{L}$ of each dilution were spotted on Solid yeast nitrogen base (YNB) medium (without amino acids Ura) SC-Ura medium containing a range of metal salts, including $\mathrm{KCl}, \mathrm{AgCl}, \mathrm{CdCl}_{2}, \mathrm{ZnCl}_{2}, \mathrm{MgCl}_{2}, \mathrm{BaCl}_{2}, \mathrm{MnCl}_{2}, \mathrm{CaCl}_{2}$, $\mathrm{NiSO}_{4}, \mathrm{CuCl}_{2}, \mathrm{CoCl}_{2}, \mathrm{AlCl}_{3}, \mathrm{FeCl}_{3}, \mathrm{NaCl}, \mathrm{NaHCO}_{3}, \mathrm{Na}_{2} \mathrm{CO}_{3}$, sorbitol and $\mathrm{H}_{2} \mathrm{O}_{2}$. All of the plates were incubated at $30{ }^{\circ} \mathrm{C}$ for $3-7$ days. All experiments were repeated three times.

\subsection{Northern Blot Analysis}

Total RNA was extracted using TRIzol reagent (Invitrogen, Carlsbad, CA, USA) from various organs of $P$. tenuiflora and cultured $P$. tenuiflora cells treated with $200 \mathrm{mM} \mathrm{NaCl}$ for $0,6,12,24$ and $48 \mathrm{~h}$. For northern blot analysis, hybridization signals were detected using anti-DIG antibody conjugated with alkaline phosphatase (Roche, Indianapolis, IN, USA) and CDP-Star (Roche), as described by Sambrook et al. [41]. Signals were detected using a luminescent image analyzer (Fujifilm, LAS-4000 mini, Tokyo, Japan).

\section{Conclusions}

In all, 32 FOX-yeast lines that had stronger tolerance to salt stress, alkali stress, osmotic stress and oxidative stress were identified. These results suggest that the FOX hunting system is a rapid and effective tool for the isolation of stress tolerance genes.

In this study, two genes ( $\mathrm{NaCl}-158^{\#}$ and $\left.\mathrm{NaCl}-167^{\#}\right)$ that conferred salt resistance were isolated using this method; intriguingly, these genes had only low homology with those from some lower organisms, and their functions were not yet known. In this regard, the resistance of transformed yeast to salt, alkaline conditions, osmotic stress and heavy metals indicates that the protective effect of both of the genes is directed via a common cellular pathway that is activated by all of these stresses. The oxidative stress pathway might be a prime candidate in this regard. In the future, we intend to elucidate the specific molecular mechanisms by which these genes exert their activity.

\section{Acknowledgments}

This work was supported by the Natural Science Foundation of Heilongjiang Province (C201406), the Program for Innovative Research Team by Chinese Ministry of Education (IRT13053), the Fundamental Research Funds for the Central Universities (2572014BA20) and The Open Project of the Key Laboratory of Crop Germplasm Improvement and Cultivation in Cold Regions of Heilongjiang Province (CGIC201204), awarded to Ying Li. We thank Editage for providing English editing services. 


\section{Author Contributions}

Ying Li and Shenkui Liu designed the study. Ying Li performed the experiments and drafted the manuscript. Shenkui Liu and Tetsuo Takano supervised the study and critically revised the manuscript. All authors read and approved the final manuscript.

\section{Conflicts of Interest}

The authors declare no conflict of interest.

\section{References}

1. Degenhardt, B.; Gimmler, H.; Hose, E.; Hartung, W. Effect of alkaline and saline substrates on ABA contents, distribution and transport in plant roots. Plant Soil 2000, 225, 83-94.

2. Greenway, H.; Munns, R. Mechanisms of salt tolerance in nonhalophytes. Annu. Rev. Plant Physiol. 1980, 31, 149-190.

3. Zhu, J.K. Salt and drought stress signal transduction in plants. Annu. Rev. Plant Biol. 2002, 53, 247-273.

4. Munns, R.; Tester, M. Mechanisms of salinity tolerance. Annu. Rev. Plant Biol. 2008, 59, 651-681.

5. Wang, C.M.; Zhang, J.L.; Liu, X.S.; Li, Z.; Wu, G.Q.; Cai, J.Y.; Flowers, T.J.; Wang, S.M. Puccinellia tenuiflora maintains a low $\mathrm{Na}^{+}$level under salinity by limiting unidirectional $\mathrm{Na}^{+}$influx resulting in a high selectivity for $\mathrm{K}^{+}$over $\mathrm{Na}^{+}$. Plant Cell Environ. 2009, 32, 486-496.

6. Wang, W.; Vinocur, B.; Altman, A. Plant responses to drought, salinity and extreme temperatures: Towards genetic engineering for stress tolerance. Planta 2003, 218, 1-14.

7. Glenn, E.P.; Brown, J.J.; Blumwald, E. Salt tolerance and crop potential of halophytes. Crit. Rev. Plant Sci. 1999, 18, 227-255.

8. Munns, R. Comparative physiology of salt and water stress. Plant Cell Environ. 2002, 25, 239-250.

9. Niu, X.; Bressan, R.A.; Hasegawa, P.M.; Pardo, J.M. Ion homeostasis in $\mathrm{NaCl}$ stress environments. Plant Physiol. 1995, 109, 735-742.

10. Yang, C.W.; Li, C.Y.; Zhang, M.L.; Liu, J.; Ju, M.; Shi, D.C. pH and ion balance in wheat-wheatgrass under salt- or alkali stress. Chin. J. Appl. Ecol. 2008, 19, 1000-1005.

11. Yeo, A. Molecular biology of salt tolerance in the context of whole-plant physiology. J. Exp. Bot. 1998, 49, 915-929.

12. Alonso, J.M.; Stepanova, A.N.; Leisse, T.J.; Kim, C.J.; Chen, H.; Shinn, P.; Stevenson, D.K.; Zimmerman, J.; Barajas, P.; Cheuk, R.; et al. Genome-wide insertional mutagenesis of Arabidopsis thaliana. Science 2003, 301, 653-657.

13. Hirochika, H.; Guiderdoni, E.; An, G.; Hsing, Y.I.; Eun, M.Y.; Han, C.D.; Upadhyaya, N.; Ramachandran, S.; Zhang, Q.; Pereira, A.; et al. Rice mutant resources for gene discovery. Plant Mol. Biol. 2004, 54, 325-334.

14. Hsing, Y.I.; Chern, C.G.; Fan, M.J.; Lu, P.C.; Chen, K.T.; Lo, S.F.; Sun, P.K.; Ho, S.L.; Lee, K.W.; Wang, Y.C.; et al. A rice gene activation/knockout mutant resource for high throughput functional genomics. Plant Mol. Biol. 2007, 63, 351-364. 
15. Kolesnik, T.; Szeverenyi, I.; Bachmann, D.; Kumar, C.S.; Jiang, S.; Ramamoorthy, R.; Cai, M.; Ma, Z.G.; Sundaresan, V.; Ramachandran, S. Establishing an efficient $A c / D s$ tagging system in rice: large-scale analysis of $D s$ flanking sequences. Plant J. 2004, 37, 301-314.

16. Kuromori, T.; Hirayama, T.; Kiyosue, Y.; Takabe, H.; Mizukado, S.; Sakurai, T.; Akiyama, K.; Kamiya, A.; Ito, T.; Shinozaki, K. A collection of 11800 single-copy Ds transposon insertion lines in Arabidopsis. Plant J. 2004, 37, 897-905.

17. Li, J.; Lease, K.A.; Tax, F.E.; Walker, J.C. BRS1, a serine carboxypeptidase, regulates BRI1 signaling in Arabidopsis thaliana. Proc.Natl. Acad. Sci. USA 2001, 98, 5916-5921.

18. Nakazawa, M.; Ichikawa, T.; Ishikawa, A.; Kobayashi, H.; Tsuhara, Y.; Kawashima, M.; Suzuki, K.; Muto, S.; Matsui, M. Activation tagging, a novel tool to dissect the functions of a gene family. Plant J. 2003, 34, 741-750.

19. Upadhyaya, N.M.; Zhou, X.-R.; Zhu, Q.-H.; Ramm, K.; Wu, L.; Eamens, A.; Sivakumar, R.; Kato, T.; Yun, D.-W.; Santhoshkumar, C.; et al. An $i A c / D s$ gene and enhancer trapping system for insertional mutagenesis in rice. Funct. Plant Biol. 2002, 29, 547-559.

20. Van Enckevort, L.J.; Droc, G.; Piffanelli, P.; Greco, R.; Gagneur, C.; Weber, C.; Gonzalez, V.M.; Cabot, P.; Fornara, F.; Berri, S.; et al. EU-OSTID: A collection of transposon insertional mutants for functional genomics in rice. Plant Mol. Biol. 2005, 59, 99-110.

21. Weigel, D.; Ahn, J.H.; Blazquez, M.A.; Borevitz, J.O.; Christensen, S.K.; Fankhauser, C.; Ferrandiz, C.; Kardailsky, I.; Malancharuvil, E.J.; Neff, M.M.; et al. Activation tagging in Arabidopsis. Plant Physiol. 2000, 122,1003-1013.

22. Yoshizumi, T.; Tsumoto, Y.; Takiguchi, T.; Nagata, N.; Yamamoto, Y.Y.; Kawashima, M.; Ichikawa, T.; Nakazawa, M.; Yamamoto, N.; Matsui, M. Increased level of polyploidy1, a conserved repressor of CYCLINA2 transcription, controls endoreduplication in Arabidopsis. Plant Cell 2006, 18, 2452-2468.

23. Ichikawa, T.; Nakazawa, M.; Kawashima, M.; Iizumi, H.; Kuroda, H.; Kondou, Y.; Tsuhara, Y.; Suzuki, K.; Ishikawa, A.; Seki, M.; et al. The FOX hunting system: An alternative gain-of-function gene hunting technique. Plant J. 2006, 48, 974-985.

24. Nakamura, H.; Hakata, M.; Amano, K.; Miyao, A.; Toki, N.; Kajikawa, M.; Pang, J.; Higashi, N.; Ando, S.; Toki, S.; et al. A genome-wide gain-of function analysis of rice genes using the FOX-hunting system. Plant Mol. Biol. 2007, 65, 357-371.

25. Du, J.; Huang, Y.P.; Xi, J.; Cao, M.J.; Ni, W.S.; Chen, X.; Zhu, J.K.; Oliver, D.J.; Xiang, C.B. Functional gene-mining for salt-tolerance genes with the power of Arabidopsis. Plant J. 2008, 56, 653-664.

26. Himuro, Y.; Tanaka, H.; Hashiguchi, M.; Ichikawa, T.; Nakazawa, M.; Seki, M.; Fujita, M.; Shinozaki, K.; Matsui, M.; Akashi, R.; et al. FOX-superroots of Lotus corniculatus, overexpressing Arabidopsis full-length cDNA, show stable variations in morphological traits. J. Plant Physiol. 2011, 168, 181-187.

27. Liu, X.; Chen, X.; Oliver, D.J.; Xiang, C.B. Isolation of a low-sulfur tolerance gene from Eichhornia crassipes using a functional gene-mining approach. Planta 2009, 231, 211-219.

28. Wan, C.G.; Zou, X. A study on salt tolerance of Puccinellia chinampoensis and its' desalinizing effect on the soil. Pratacult. Sci. 1990, 3, 3-8. 
29. Peng, Y.H.; Zhu, Y.F.; Mao, Y.Q.; Wang, S.M.; Su, W.A.; Tang, Z.C. Alkali grass resists salt stress through high $\left[\mathrm{K}^{+}\right]$and an endodermis barrier to $\mathrm{Na}^{+}$. J. Exp. Bot. 2004, 55, 939-949.

30. Wang, Y.; Chu, Y.; Liu, G.; Wang, M.H.; Jiang, J.; Hou, Y.; Qu, G.; Yang, C. Identification of expressed sequence tags in an alkali grass (Puccinellia tenuiflora) cDNA library. J. Plant Physiol. 2007, 164, 78-89.

31. Wang, Y.; Yang, C.; Liu, G.; Jiang, J. Development of a cDNA microarray to identify gene expression of Puccinellia tenuiflora under saline-alkali stress. Plant Physiol. Biochem. 2007, 45, 567-576.

32. Liu, H.; Zhang, X.; Takano, T.; Liu, S. Characterization of a PutCAX1 gene from Puccinellia tenuiflora that confers $\mathrm{Ca}^{2+}$ and $\mathrm{Ba}^{2+}$ tolerance in yeast. Biochem. Biophys. Res. Commun. 2009, 383, 392-396.

33. National Center for Biotechnology Information. Available online: http://www.ncbi.nlm.nih.gov (accessed on 12 September 2014).

34. ORF Finder. Available online: http://www.ncbi.nlm.nih.gov/gorf/orfig.cgi (accessed on 12 September 2014).

35. TMHMM-2.0. Available online: http://www.cbs. dtu.dk/services/TMHMM-2.0/ (accessed on 12 September 2014).

36. Dat, J.; Vandenabeele, S.; Vranova, E.; van Montagu, M.; Inze, D.; van Breusegem, F. Dual action of the active oxygen species during plant stress responses. Cell. Mol. Life Sci. CMLS 2000, 57, 779-795.

37. Foyer, C.H.; Noctor, G. Oxidant and antioxidant signalling in plants: A re-evaluation of the concept of oxidative stress in a physiological context. Plant Cell Environ. 2005, 28, 1056-1071.

38. Gomez, J.M.; Hernandez, J.A.; Jimenez, A.; del Rio, L.A.; Sevilla, F. Differential response of antioxidative enzymes of chloroplasts and mitochondria to long-term $\mathrm{NaCl}$ stress of pea plants. Free Radic. Res. 1999, 31, S11-S18.

39. Van Assche, F.; Clijsters, H. Effects of metals on enzyme activity in plants. Plant Cell Environ. 1990, 13, 195-206.

40. Gietz, R.D.; Schiestl, R.H.; Willems, A.R.; Woods, R.A. Studies on the transformation of intact yeast cells by the LiAc/SS-DNA/PEG procedure. Yeast 1995, 11, 355-360.

41. Sambrook, J.; Russell, D.W. Molecular Cloning: A Laboratory Manual, 3rd ed.; Cold Spring Harbor Laboratory Press: Cold Spring Harbor, NY, USA, 2001.

(C) 2014 by the authors; licensee MDPI, Basel, Switzerland. This article is an open access article distributed under the terms and conditions of the Creative Commons Attribution license (http://creativecommons.org/licenses/by/3.0/). 